\title{
Conditions for Exercising the Exception of Non-Performance
}

\author{
By Maria Căzănel
}

From a legal perspective, the legally binding contract has the force of law between the parties; thus, problems arise when the debtor fails to fulfil its obligations, by breach of the principle pacta sunt servanda, creating an imbalance between the contracting parties in relation to the other contractor, which fulfilled its own obligations or stated that it is ready to execute them. In this paper, we will try to discern the conditions of the legal mechanism of non-performance, which consists in the right of the creditor that fulfilled an obligation (or stated that it is ready to execute it), under a mutually binding contract, to apply this remedy consisting in the refusal to execute the obligation incumbent upon it until the debtor executes its own obligation. The major advantage of this legal institution is that it can be invoked directly between the parties to the mutually binding contract, without the need for court intervention. Also, in the event of a dispute, the excipiens can easily paralyze the legal action brought by the debtor that did not to fulfil its obligations, invoking the exceptio non adimpleti contractus.

- the mutual obligations of the parties are under the same mutually binding contract;

- there is a non-performance, even a partial one, but significant enough, of the other contractor;

- by its nature, the mutually binding legal relationship involves the rule of the simultaneous execution of the mutual obligations by both parties;

- the reciprocal obligations are both eligible;

- the non-performance is not triggered by the act itself of the party that invokes the exception.

Keywords: Contract; Non-performance; Obligations; Creditor; Debtor

\section{Introduction}

The exception of contract non-performance is a legal institution that has a wide practical application. However, in the absence of express regulations, it was not possible to analyse it as a whole, triggering, across time, many theoretical controversies. The opportunity of this mechanism is nuanced by jurisprudence, with varying interpretations, as its legal basis has not been fully clarified yet, being considered by some authors as "an indirect way for the nonperformance of contractual obligations" ${ }^{1}$.

Through this mechanism, i.e. the exception of non-performance, the contractor who has acted in good faith can suspend (without any court

\footnotetext{
* PhD Lecturer, Faculty of Law and Administrative Sciences, Ovidius University of Constanta, Romania.

${ }^{1}$ Malaurie, Aynès \& Stoffel-Munck (2010) at p. 475.
} 
intervention) the performance of its own obligations until the other contracting party has fulfilled its incumbent obligations. Once the co-contractor performs its obligation, the suspensive effect of non-performance shall cease.

Thus, the exception non adimpleti contractus consists of an enforcement refusal, acting as a tool for achieving private justice, because it operates without the prior intervention of a judge and without formal notice to the other contracting party.

\section{The Conditions for Exercising the Exception of Non-Performance of Contract}

In order to invoke the exception of non-performance, the following material conditions shall be met cumulatively:

- the mutual obligations of the parties must be under the same mutually binding contract;

- there must be a non-performance, even a partial one, but significant enough, of the other co-contractor;

- by its nature, the mutually binding legal relationship must involve the rule of the simultaneous performance of the mutual obligations by both parties;

- the reciprocal obligations must be both eligible;

- the non-performance must not be triggered by the act itself of the party that invokes the exception.

a) The first condition regarding the nature of the non-performed obligations is expressly provided for by art.1556, paragraph 1 of the New Civil Code, namely the mutual obligations of the parties must be under the same mutually binding contract.

This condition points out that, in order to invoke the exception of nonperformance, in addition to the fact that the two persons must be each other's creditor and debtor, their mutual obligations must arise from, and be underlain by, the same mutually binding legal relationship; this is the only way that explains the legal connection between the mutual obligations of the two parties ${ }^{2}$.

In this regard, the Decision delivered by the Court of Cassation of France on $14^{\text {th }}$ May 1938 ruled that "the interdependence of the obligations arising from a mutually binding contract that grants one party's right not to perform its obligation until the other has executed its own, involves essentially the obligations arising from the same contract". In this case, the tender book of an electricity company, concluded between the Community and the concessionaire, contained a clause referring to a minimum consumption obligation made by subscribers. By reason of one's refusal (subscriber Caylo) to observe this clause, the company cut the electric power; however, the court ordered the performance of the company's obligation to provide electric power, arguing that "in order to refuse to supply electric power to Caylo under the verbal contract concluded with him, the

\footnotetext{
${ }^{2}$ Pop (2009) at p.716.
} 
company could not find a pretext to evade the performance of an obligation entered into a tender book that did not concern him (i.e. Caylo)" ${ }^{3}$. Thus, the French authors have noted that the exception of non-performance does not apply to the obligations arising from separate agreements, even if they were concluded between the same parties, as there are no mutual obligations involved in such a situation ${ }^{4}$.

In the foreign literature, this thesis has been developed, arguing that, de plano, the parties' mutual obligations should not necessarily be part of the legal content of a mutually binding contract, but they may arise as well from another licit judicial act or fact. However, the obligations must be reciprocal and provided by the parties or by law (both parties must be each other's creditor and debtor) ${ }^{5}$. Therefore, the buyer shall be able to refuse to pay the price because the seller owes it (i.e. the buyer) an amount of money that it (i.e. the buyer) borrowed to the seller ${ }^{6}$. The two obligations are part of two different reciprocal legal relationships, so that neither party can invoke the exception of non-performance because the other party failed to perform its own obligation.

However, the French legal doctrine stated that the exception of nonperformance can also be applied when the reciprocal obligations are part of different legal relationships, but which are rooted in the existence of a general agreement such as the framework agreement ${ }^{7}$.

As previously mentioned, the exception of non-performance may also be invoked for imperfect synallagmatic contracts, for the reasons set out in Title I, Chapter 2 of the paper ${ }^{8}$. The doctrine considers that the exception of nonperformance should be extended to all reciprocal relationships, even if they do

\footnotetext{
${ }^{3}$ Case in Malaurie, Aynès \& Stoffel-Munck (2010) at p.474.

${ }^{4}$ The Court of Cassation, Commercial Division, on $26^{\text {th }}$ November 1973, Civil Bulletin V, no. 340, cited in Malaurie, Aynès \& Stoffel-Munck at p. 474, stated that, in this case, the company Cleyet-Marrel (later in bankruptcy) yielded to the society "La Cellonite" brands and production means in return for royalties; it also committed to yield to the same company the stock of already manufactured products. It was decided that the company $\mathrm{C}$ could not refuse the payment of the royalties due, because the promised stock had not been delivered for the following reasons: The Court of Appeal states that "sum whose payment is claimed by the syndic is not in any way the price of the undelivered goods"; it showed that each of the two separate Conventions concluded between the parties - assignment of brands and production means in return for a royalty on the one hand, and sale of stock in return for its price, on the other hand - was not bound by anything to the other; consequently, it could decide that the nonperformance (affirmed by "La Cellonite") of the obligations contracted by the company CleyetMarrel, regarding the sale of stocks, did not allow "La Cellonite" to suspend the payment of royalties, counterpart for the assignment of the above-mentioned brands and production means, properly performed by the company Cleyet-Marrel".

${ }^{5}$ Malecki (1999) at pp.246-255.

${ }^{6}$ Pop, Popa \& Vidu (2012) at p.274.

${ }^{7}$ The French jurisprudence held, in a court decision, that the mechanic may refuse to return a bus because he was not paid the costs of previous repairs performed under a general agreement regarding the repair of the respective customer's fleet vehicle as cited in Pop (2009) at p. 717.

${ }^{8}$ Malaurie, Aynès \& Stoffel-Munck (2010) at p.474.
} 
not result from a contract, such as the refunds subsequent to contract termination or nullity ${ }^{9}$.

Also, in terms of the relationship between the two obligations, in the legal literature, it has been shown that the exception of non-performance is distinct from the lien. The exception of non-performance can lead to a situation where the party owing a good refuses to deliver it; this situation appears to be assimilated with the lien. In reality, the two notions remain different, even if their outcome may be the same because, as far as the lien is concerned, there is a factual connection between the debt and the respective good; on the other hand, as far as the exception of non-performance is concerned, the connection is legal and it arises from the causal interdependence of contractual obligations ${ }^{10}$.

On the other hand, there are obligations arising from reciprocal legal relationships that are incompatible with performance refusal, such as the obligations whose object disappeared because of force majeure ${ }^{11}$. In this case, the contract shall terminate ipso jure, without notice, even from the moment when the event took place. In other cases, the refusal to perform one's obligations is prohibited by the mandatory legal rules for the special protection of certain categories of people, such as the obligation to pay wages, governed by labour law ${ }^{12}$. Also, the excipiens (i.e. party raising the defines that the plaintiff has not performed its part of the contract) cannot refuse to return a good that would hinder the proper functioning of a public service, such as the urgent expropriation in the public interest ${ }^{13}$. Moreover, art. 1556, paragraph 1 of the New Civil Code provides for the possibility to establish that the other party is bound to perform its obligations first; this possibility may be established under the law, by the will of the contracting parties and by various usages in the field. In this context, the excipiens shall not be able to invoke the exception of nonperformance, unless it does it by itself, although it is not obliged to perform its obligation first.

b) The provisions of art.1556, paragraph 1 of the new Civil Code reveal another condition necessary in order to invoke this exception, i.e. there must be a nonperformance of obligations, even a partial one, but significant enough, of the other contractor.

In the legal literature, it has been shown that the reason for non-performance does not matter; this reason may be represented by the debtor's fault or by the force majeure that, for the moment, prevents the debtor to perform the obligation it is responsible for. If, however, the non-performance triggered by force majeure is final, we are in the presence of contract termination by reason of accidental impossibility of performance. ${ }^{14}$

\footnotetext{
${ }^{9}$ Pop (2009) at p.708; Kocsis (1999) at p. 9; Pop, Popa \& Vidu (2012) at p.274; Malaurie, Aynès \& Stoffel-Munck (2010) at p.473.

${ }^{10}$ Pop, Popa \& Vidu (2012) at p.274; Vidu (2010) at pp.17-44.

${ }^{11}$ Malecki (1999) at p.255.

12 Articles 159-171, the Labour Code republished by Law no.53/2003, in the Official Gazette no. 345 of 18.05.2011;

${ }_{13}^{13}$ Malecki,(1999) at pp.491-492; Pop (2009) at p.717.

${ }^{14}$ Pop, Popa \& Vidu (2012) at p.274; Malaurie, Aynès \& Stoffel-Munck,(2010) at p.474.
} 
The party invoking the exceptio non adimpleti contractus is not required to prove that the non-performance is due to the debtor's guilt; it is sufficient to prove only the fact of non-performance ${ }^{15}$. Moreover, unlike the previous Civil Code, which details the guilt, calling it either "mistake" (art. 998) or "negligence" or "recklessness" (art. 999), the new Romanian Civil Code establishes, under art.1548, the guilt presumption of the debtor of a contractual obligation ${ }^{16}$. Thus, proving the contract non-performance triggers the guilt presumption of the debtor of the respective obligation ${ }^{17}$.

In legal doctrine, it was noted that the non-performance of obligations can be viewed broadly, when this notion means non-performance, improper performance or delayed performance of obligations, or narrowly, when it designates only the total or partial non-performance of contractual obligations ${ }^{18}$. Thus, the non-performance can be:

- total non-performance, which involves the complete non-performance of contractual obligations (for example, failure to deliver the goods sold by the seller),

- partial non-performance, which involves the partial non-fulfilment of one's obligations, but which must be of a certain severity, justifying the need for invoking this exception (for example, the seller delivered only half of the contracted goods).

In this respect, the explicit regulation of art.1556, paragraph 2 of the New Civil Code is absolutely beneficial. This regulation introduces a legal criterion of proportionality, i.e. the non-performance should be sufficiently important in order to grant the excipiens the right to use this remedy. Thus, it is unjustified

\footnotetext{
${ }^{15}$ In this regard, the Supreme Tribunal, the Civil Section, ruled, by Decision no.366/1971, that "in principle, the debtor is responsible for the non-performance of the obligation, unless it proves that the non-performance is attributable to external causes";

${ }^{16}$ According to the New Civil Code, art.1548, the guilt belonging to the debtor of a contractual obligation is presumed by the mere fact of non-performance;

${ }^{17}$ The Court of Bucharest, Section VI (trade), by the civil decision no.736/2005 (in Mateescu (2009) at p.55), stated that, in contractual civil liability, the debtor's guilt is presumed; under these circumstances, it is incumbent on the debtor to prove the efforts made in order to achieve the contract object, otherwise it is liable". Similarly, C.A. Bucharest, Civil Section IV, by civil decision no.149/2006, ruled that "art.1082 of the Civil Code from 1865 establishes a presumption of guilt belonging to the debtor of the non-performed contractual obligation. This text of law does not establish a legal presumption of guilt that triggers, outside the legal decision framework, the contractual liability of the debtor of the non-performed obligations; on the contrary, this presumption operates exclusively in terms of burden of proof in a legal action in contract rescission, with damages for the culpable non-performance of the obligation. In such action, the burden of proof of guilt in contract non-performance is overturned by the legislator's will, i.e. art.1082 of the Civil Code of 1865 absolves the plaintiff to make such proof, and the debtor-defendant has the burden of proving that it is not liable for contract nonperformance and that this non-performance is caused by other causes beyond its will", published in Paraschiv (2010) at p.32.

${ }^{18}$ Adam (2011) at p.373.
} 
to invoke the exception for less significant non-performances because there should be a balance between the non-performance of the two obligations ${ }^{19}$.

The judge has the power to determine whether the non-performance of a partial obligation is serious enough and s/he shall rule depending on the circumstances. We consider that the non-performance of a part of an obligation is sufficiently serious when it represents the essential cause of the contract. In this context, the party that is not at fault can even ask for contract termination through rescission.

The legal literature reveals that, if the excipiens receives a partial payment, it means that it accepted it and, therefore, it gave up the advantages granted by the principle of payment indivisibility, established under art. 1516 of the New Civil Code. According to this article, "the creditor is entitled to the full, accurate and timely fulfilment of the obligation" ${ }^{20}$. In this regard, it was noted that a contractor who receives a partial service shall not be able to abuse by invoking the exception of non-performance in order to free itself from the performance of its own obligation. The contractor shall be able to suspend the performance of its own obligation only proportionally with the part of the obligation that was not performed by the other contracting party ${ }^{21}$.

On the other hand, the legal doctrine tackled the question whether the nonperformance of an ancillary obligation can justify the recourse to this exception. Thus, it was shown that, as far as the lease agreement is concerned, ensuring the use of the leased property is sufficient in order to demand for the payment of the rent, even if the lessor has not made the repairs incumbent upon $\mathrm{it}^{22}$. Although the jurisprudence does not distinguish between primary and secondary obligations, it however claims that the non-performance should be sufficiently serious ${ }^{23}$. Moreover, a partial performance does not represent the fulfillment of the obligation; on the contrary, in reality, it is also a nonperformance, as stipulated by the provisions of art.1516 from the New Civil Code.

Therefore, we consider it appropriate that the courts should admit the exception of the partial non-performance of the obligation, because otherwise, it would encourage the mala fide debtor to prevent the use of this defensive means by the excipiens.

At the same time, the excipiens must invoke the exception in good faith, because it should not become a blackmail instrument against the other contracting party. In legal literature, it has been shown that, like the self-defence applied in criminal law, the exception of non-performance should be proportionate to the seriousness of the respective non-performance ${ }^{24}$. Moreover, the exception

\footnotetext{
${ }^{19}$ Pop, Popa \& Vidu (2012) at p.275.

${ }^{20}$ Pop (2009) at p.718; Stătescu \& Bîrsan (2008) at p.310.

${ }^{21}$ Bénabent (2001) at p.251.

${ }^{22}$ The Court of Cassation, Civil Division 1, the $26^{\text {th }}$ May 1961, Civil Bulletin I 264, p.209; The Court of Cassation, Civil Division 3, $21^{\text {st }}$ November 1973, Civil Bulletin III, no.593, p.432 (in Pop (2009) at 718.

${ }^{23}$ Pop (2009) at p.718.

${ }^{24}$ Pop (2009) at p.718; Malecki (1999) at 279-302; The Court of Cassation, Commercial Division, the $16^{\text {th }}$ July 1980, Civil Bulletin IV, no.297 (cited in Malaurie, Aynès \& Stoffel-
} 
should not be admitted when the conduct of the party invoking it put the cocontractor in the position of being unable to pay what it owed; this behaviour shows mala fide and shall be sanctioned by the court by rejecting the exception of non-performance ${ }^{25}$.

c) The third condition for exercising the exception of non-performance stipulated that, by its nature, the mutually binding legal relationship must involve the rule of the simultaneous performance of the mutual obligations by both parties.

In order to be effective, the exception of non-performance must involve the simultaneous performance of the parties' mutual obligations, i.e. they must be performed at the same time or, at most, immediately one after the other (for example, in the sale contract, the buyer pays the price and, at the same time, the seller delivers the buyer the good that the former bought; if one of them fails to perform its obligation, the other party may suspend the performance of its own obligation) ${ }^{26}$.

The legal literature revealed that, in order to understand these circumstances, we should refer to the provisions of art.1555 of the New Civil Code, which provides for the principle of the simultaneous performance of obligations ${ }^{27}$. The exceptions to this rule are reflected by the situations when:

- the parties have provided for a certain order of service performance;

- certain usages may require a contractor the duty to first perform its own obligations; thus, it will not be able to invoke the exception of nonperformance (the hotelier fulfils its contractual obligations towards the

\footnotetext{
Munck (2010) at p.475), ruled that "the court should consider whether the seller complied with its obligations and if, eventually, its non-performance was serious enough to release the buyer from its own correlative obligations". In this case, a deliver asked for the payment of the sum of 1,295 F, representing the price of the goods sold, among which there was a leather jacket with a value of $500 \mathrm{~F}$; the buyer refused to pay, claiming that the jacket had a defect; the court ordered the buyer to pay, arguing that the seller had made the reasonable efforts in order to repair the defects;

${ }^{25}$ In this regard, the HCCJ ruled, in the civil and intellectual property section, by Decision no.5013/19.06.2007, arguing that "the definition of the exception of contract non-performance reveals that it can be successfully invoked until the opposing party has performed its obligation or declares that it wants to execute its own obligation, the existence of any dispute between the parties being thus irrelevant. In order to verify the fulfilment of the conditions of the exception of non-performance, there should be considered the source of the mutual obligations, the obligations undertaken by the parties under the contract, that are allegedly unperformed obligations, their importance in the contract content, the cause of non-performance and the existence or inexistence of the simultaneity of obligations. In this case, given the interdependence of the mutual obligations under the contract, each obligation representing the legal cause of the correlative obligation, the defines plea made by the recurrent by invoking the exception of nonperformance shall be rejected because the non-performance was triggered by its own act, which prevented the plaintiffs to perform their own obligations".

${ }^{26}$ Pop (2009) at p.719.

${ }^{27}$ According to art.1555, paragraph 1 of the New Civil Code if the agreement between the parties or the circumstances indicate otherwise, to the extent that the obligations can be performed simultaneously, the parties are obliged to perform them in this way;
} 
tourist and presents the bill only upon the tourist's departure or after a certain time from the start of the tourist's stay; at the restaurant, the payment is made only after consumption ${ }^{28}$ );

- according to art. 1555, paragraph 2 of the New Civil Code, if the performance of the obligation by one party requires a certain timeperiod, the respective party is bound to perform its obligation the first;

- the exception of non-performance is removed if one party grants to the other a deadline for the performance of its obligations (in the credit sale, the seller cannot refuse the delivery of the asset sold because the price set was not paid immediately by the buyer $)^{29}$.

In this respect, the jurisprudence stated that "The essential feature of mutually binding contracts is represented by the reciprocity and interdependence of the obligations incumbent upon the parties, by the fact that each mutual obligation is the legal cause of the correlative obligation, involving the simultaneous performance of these obligations, therefore the possibility to invoke the exception of non-performance, when the simultaneity is not met. As such, the exceptio non adimpleti contractus is a penalty because the party seeking the performance of the obligation does not intend to fulfil its own contractual duties, which it has undertaken. In this case, the plaintiff has notified the defendant to go to its lawyer's office, for the collection of the amount representing the second part of the advance money, the notification mentioning, however, that if the promissory-seller does not come, the amount shall be registered at CEC, in its name. Instead of complying with this obligation, the plaintiff has sought to re-notify the defendant to go to the public notary's office in order to pay the difference in price and to sign and authenticate the contract.

Moreover, the plaintiff registered in the bank the amount for the second part of the advance money in its name and not in the defendant's name and disposal. Or, only the real offer followed by the accord could free the plaintiff from the obligation undertaken by the pre-contract". ${ }^{30}$

d) The mutual obligations must be both exigible; art.1556, paragraph 1 of the new Civil Code reveals that the exception of non-performance may be invoked only if the mutual obligations are matured or must be carried out immediately, under the rules laid down in art.1495, paragraph 1 of the New Civil Code concerning the payment of time-free obligations (i.e. obligations that have no deadline) ${ }^{31}$.

If the parties have set a deadline for the performance of one of the obligations, the party in whose favour this deadline is stipulated may invoke the benefit of payment by instalments under the provisions of art.1413 of the New Civil Code, provided that it has not been insolvent or that it has not

\footnotetext{
${ }^{28}$ Pop (2009) at p.719.

${ }^{29}$ Malaurie, Aynès \& Stoffel-Munck (2010) at p.473.

${ }^{30} \mathrm{HCCJ}$, civil and intellectual property section, December no.5457/2004 www.scj.ro

${ }^{31}$ Stătescu \& Bîrsan (2008) at p.315.
} 
reduced the guarantees granted to its creditor, under the contract. In this case, the debtor shall be deprived of the benefit of payment by instalments, under art.1417, paragraph 1 of the New Civil Code. As such, the exception of contract non-performance can be successfully invoked against $\mathrm{it}^{32}$.

However, the legal literature revealed that the exception of non-performance may be invoked in situations where the parties' obligations do not have to be simultaneously performed, being affected by a deadline. In this case, it is important that this type of obligation (i.e. the time-dependent obligation), belonging to the party against which the exception is invoked, become exigible before the call date of the excipiens' contractual obligations ${ }^{33}$.

The French doctrine considers that, where there is doubt about the performance of time-dependent obligations (i.e. obligations with a certain deadline), the creditor of that obligation may, by derogation from the rules of common law, request and obtain the suspension of its own obligations, which is actually an anticipated exception of non-performance, acting as a guarantee, accepted even before the excipiens' right of claim reaches its call date ${ }^{34}$.

In legal literature, it has been shown that the remedy of the anticipated exception of non-performance, which is frequently found in comparative law ${ }^{35}$, it is fully permissible under the New Romanian Civil $\operatorname{Code}^{36}$ :

- for the additional performance period, if the debtor declares, before it expires, that it shall not carry out its obligations, the creditor is entitled to invoke anticipatedly any remedies that it considers appropriate, under art.1522, paragraph 4 of the New Civil Code; the same reason subsists for the standstill period of performance;

- as already mentioned, regarding the regulation of the standstill period of performance and the failure to meet the deadline, art.1417 of the New Civil Code entitles the creditor to invoke an anticipated exception of non-performance.

The provisions related to the exception of non-performance also apply to contracts of international trade law, which govern the institution for the suspension of the performance of one's own obligations in anticipation of non-performance ${ }^{37}$.

In this regard, we mention the provisions of art.7.3.4, from the UNIDROIT Principles, stating that "a party who reasonably believes that there will be a fundamental non-performance by the other party may demand an adequate assurance of due performance and may meanwhile withhold its own

\footnotetext{
${ }^{32}$ According to art.1417, paragraph 1 of the new Civil Code, the debtor shall lose the benefit of the deadline if it is insolvent or, where appropriate, if it declared insolvency under the law, and where, intentionally or due to serious misconduct, it diminished by its action the guarantees established in the creditor's favour or when it does not establish the guarantees promised;

${ }^{33}$ Kocsis (1999) at p.15.

${ }^{34}$ Pop (2009) at p.719.

${ }^{35}$ The anticipated exception of non-performance is a common solution in the European national law: art.321 Bürgerliches Gesetzbuch and in international trade.

${ }^{36}$ Pop, Popa \& Vidu (2012) at p. 275.

${ }^{37}$ Popa (2008) at p. 240-242.
} 
performance". Similarly, art. 71 of the Vienna Convention on the International Sale of Goods of 1980 entitles the contracting party that foresees the nonperformance of the still not yet due obligation of the other party to refuse the performance of its own mutual obligation, even if it is maturing. These provisions are designed to protect the interests of a contracting party that has reasonable grounds to believe that the other party shall not perform or cannot perform the contract upon the maturity of its obligations ${ }^{38}$.

e) The non-performance must not be triggered by the act itself of the party that invokes the exception, which prevented the other co-contractor to perform its own obligation ${ }^{39}$. Thus, if the party invoking the exception of non-performance prevented the other party to perform its own obligation, the former party commits an abuse of law whose penalty consists in the refusal to protect the right that rose from the respective contract.

This concept is specifically regulated by the provisions of art.1517 of the New Civil Code, which provides the following: "A party may not invoke the exception of the non-performance of the other party's obligations if this nonperformance is caused by the former party's own act or omission", enshrining thus the principle of the non-invocation of one's own guilt in the performance of obligations.

The legal literature states that a contract rescission shall not intervene when the non-performance of the obligation is attributable to the creditor, i.e. when the non-performance is caused by the creditor's action or inaction. Moreover, the debtor shall not respond when the non-performance is attributable exclusively to the creditor; also, if there is any damage attributable to the creditor, under art.1534, paragraph 1 of the New Civil Code, the damages owed by the debtor will decrease accordingly ${ }^{40}$.

Moreover, we consider that the exception of non-performance cannot be invoked by the excipiens of whose guilt the debtor was able to fulfil its obligation only by violating the principle of good faith.

\section{Conclusions}

As shown, in order to invoke the exception of contract non-performance, it is necessary to fulfil all the following material conditions:

- the mutual obligations of the parties must be under the same mutually binding contract;

- there must be a non-performance, even a partial one, but significant enough, of the other contractor;

\footnotetext{
${ }^{38}$ Pop (2009) at p.720.

39 Stătescu \& Bîrsan (2008) at p.87.

${ }^{40}$ Boroi \& Stănciulescu (2012) at p. 183.
} 
- by its nature, the mutually binding legal relationship must involve the rule of the simultaneous performance of the mutual obligations by both parties;

- the reciprocal obligations must be both exigible;

- the non-performance must not be triggered by the act itself of the party that invokes the exception.

The condition regarding the nature of the non-performed obligations emphasizes that the mutual obligations between the parties must arise from, and be underlain by the same mutually binding legal relationship; this explains the legal connection between the mutual obligations of the two parties. As explained by the legal doctrine, the obligations can also arise from another licit judicial act or fact; however, it must have a reciprocal nature, provided by the parties or by law (both parties must be each other's creditor and debtor).

At the same time, it has been stated that the exception of non-performance can also be applied when the reciprocal obligations are part of different legal relationships, but which originate from the existence of a general agreement, such as the framework agreement.

As previously mentioned, the exception of non-performance may be invoked in imperfect synallagmatic contracts, and the doctrine considers that the exception of contract non-performance should be extended to all such reciprocal relationships, even if it these does not result from a contract.

On the other hand, the exception of non-performance is distinct from the lien even if their outcome may be the same because, as far as the lien is concerned, there is a factual connection between the debt and the respective good. On the other hand, as far as the exception of non-performance is concerned, the connection is legal and it arises from the causal interdependence of contractual obligations.

Another prerequisite for invoking the exception is the existence of nonperformance, even a partial one, but significant enough, by the other contractor. The reason for non-performance does not matter; it may be represented by the debtor's guilt or even by the force majeure that, for the moment, prevents the debtor to perform the obligation under its responsibility. If, however, the nonperformance triggered by the force majeure is final, we are in the presence of contract termination by reason of accidental impossibility of performance.

The excipiens does not have to prove that the non-performance is triggered by the debtor's guilt; it is sufficient to prove only the existence of nonperformance, presuming the guilt of the debtor of the respective obligation. Instead, art.1556, paragraph 2 of the New Civil Code introduces a legal criterion of proportionality as follows: the non-performance should be sufficiently important in order to grant the excipiens the right to use this remedy, because there should be a balance between the non-performance of the two obligations.

At the same time, in order to invoke the exception of non-performance, the contractual relationship, by its nature, should involve the rule of the simultaneous performance of the obligations by the two parties. Thus, the performance of the parties' mutual obligations should take place at the same time or, at most, 
immediately one after the other, in accordance with art.1555 of the New Civil Code, which lays down the principle of the simultaneous performance of the parties' obligations.

Another condition is that the mutual obligations should be both exigible. According to art.1556, paragraph 1 of the new Civil Code, the exception of non-performance may be invoked only if the mutual obligations are matured or if they must be carried out immediately, under the rules laid down by art.1495, paragraph 1 of the new Civil Code concerning the payment of time-free obligations.

However, the exception of non-performance can also be invoked in situations where the parties' obligations do not require a simultaneous performance, being affected by a deadline, in which case the time-dependent obligation of the party against whom it is invoked should be exigible before the call date of the excipiens' contractual obligations.

As noted, the French doctrine considers that the creditor of the respective obligation may request and obtain the suspension of its own obligation, when there is doubt about the performance of the time-dependent obligation. This is actually an anticipated exception of non-performance, acting as a guarantee, accepted even before the call date of the excipiens' right of claim.

In addition, the non-performance of the debtor's obligation should not be triggered by the act itself of the party invoking the exception, act that prevented other co-contractor to perform its own obligation, because it would mean that the excipiens commits an abuse of law, whose penalty is the refusal to protect the right born from the respective contract. Thus, art.1517 of the New Civil Code establishes the principle of non-invoking one's own guilt in the nonperformance of obligations.

\section{References}

Adam, I. (2011). Drept civil. Obligațiile. Contractul în reglementarea Noului Cod civil. Ed.C.H.Beck; București

Bénabent, A. (2001). Droit civil. Les obligations. Montchrestien; Paris.

Boroi, G. \& L. Stănciulescu (2012). Instituții de drept civil în reglementarea noului Cod civil. Ed. Hamangiu: București.

Kocsis, J. (1999). "Excepția de neexecutare, sancțiune a neîndeplinirii obligațiilor civile contractuale", in Dreptul 1999 (4).

Malaurie, Ph., Aynès, L., \& Ph. Stoffel-Munck (2010). Drept civil. Obligațiile. Ed. Wolters Kluwer: București.

Malecki, C., (1999). L'exception d'inexécution. Ed. LGDJ: Paris.

Mateescu, A.-M. (2009). Daunele-interese în materie comercială. Practică judiciară. $2^{\text {nd }}$ ed. Ed. Hamangiu; București.

Paraschiv, M. (2010). Prezumțiile în materie civilă. Prezumțiile legale relative. Practică judiciară. Ed. Hamangiu: București.

Pop, L. (2009). Tratat de drept civil. Obligațiile. Contractul, vol.II, Ed. C.H.Beck, București.

Pop, L., Popa, I.F. \& S.I. Vidu (2012). Tratat elementar de drept civil. Obligațiile conform Noului Cod civil. ”, Ed. Universul Juridic: București. 
Popa, I..F. (2008). "Remediile neexecutării contractului de vânzare-cumpărare, din perspective Convenției de la Viena privind vânzarea internatională de mărfuri”, in RRDP 2008 (2).

Stătescu, C. \& C. Bîrsan (2008). Drept civil. Teoria generală a obligațiilor, ed. 9. Ed. Hamangiu: București.

Vasilescu, P. (2012). Drept civil. Obligațiile în reglementarea noului Cod civil. Ed. Hamangiu: București.

Vidu, S.I. (2010). Dreptul de retenție în raporturile juridice civile. Ed. Universul juridic: București. 
